\title{
The Effects of Auditor Professionalism, Experience, and Ethics on Materiality Considerations (An Empirical Study Government Auditors in Makassar)
}

\author{
Rasyidah Nadir ${ }^{1}$, Dien Triana ${ }^{1}$, Sabri Wahab ${ }^{2}$, Andi Khaerul Nasruddin ${ }^{1}$ \\ \{rasyidahnadir@gmail.com ${ }^{1}$ \} \\ Politeknik Negeri Ujung Pandang Makassar \\ Pascasarjana STIA LAN Makassar ${ }^{2}$
}

\begin{abstract}
This study aims to obtain empirical evidence on the effects of auditor professionalism on materiality considerations, auditor experience on materiality considerations, professional ethics on materiality considerations, and auditor professionalism, experience, and professionalism, experience, and professional ethics on materiality considerations simultaneously. This study was conducted on government auditors in Makassar, Indonesia. The population of the study consists of auditors employed by the BPKP Representative Office of South Sulawesi Province. The sampling process used in this study was purposive sampling. Data was collected by distributing questionnaires. The data was analyzed using multiple regression analysis. The results of this study indicate that auditor professionalism has a negative and insignificant effect on materiality considerations, auditor experience has a positive and significant effect on materiality considerations professional ethics has a negative and significant effect on materiality considerations; and auditor professionalism, experience, and professional ethics simultaneously have a positive relationship on materiality considerations.
\end{abstract}

Keywords: Auditor Professionalism, Auditor Experience, Professional Ethics, Materiality Considerations

\section{Introduction}

Auditors play a role in improving the quality and credibility of financial information. The role of both public and government auditors is urgently needed. Auditors must be neutral and independent parties to grow and increase the confidence of financial statements users. It is expected that the auditor can perform tasks systematically and critically on the financial statements that have been prepared by managers of both business and public entities.

With respect to the scope of testing, the determination of sample size and items to be tested, and auditor's judgment will have a considerable influence. Auditor considerations, in this regard, include materiality, risks, costs, benefits, size, and characteristics of the population. If the auditor is not careful in determining his or her judgment, then a mistake in the opinion statement may occur. Some factors that may affect auditor considerations in terms of materiality-level considerations are auditor professionalism, auditor experience, professional ethics, client credibility, and individual factors. 
The determination of materiality considerations is essential to assist the auditor in planning the collection of sufficiently competent evidence. Consideration of materiality is a consideration of the professional level influenced by the auditor's perception of the needs of persons with adequate knowledge and putting confidence in the financial statements.

The determination of materiality is not a new problem. Materiality is applied in almost all decisions involving economic activity. Various accounting profession institutions, the public accounting profession, the government auditor profession, capital market authority in the United States, as well as the International Accounting Standards Committee provide various views on materiality, particularly in relation to the presentation in financial statements.

The auditor should consider materiality to plan the audit and design the audit procedures. Considering materiality, auditors can design audit procedures efficiently and effectively. The financial statements may contain material misstatement if the financial statements contain misstatements whose effects, individually or entirely, are significant enough to result in the financial statements being presented unfairly in a material manner in accordance with generally accepted accounting principles.

Haynes [1] in Utami [2] suggests that many factors may affect auditor considerations particularly in evaluating audit evidence, including client preferences and audit experience. More experienced accountants will increase their knowledge in performing the audit processes, especially in giving consideration on the level of materiality in the audit process of financial statements.

The experience of the auditor is related to the consideration of the level of materiality because the auditor's experience is related to his or her expertise and knowledge in handling a case. The auditor's experience is also one of the factors that influence the auditor's judgment. The experience of the auditor refers to experience in performing the audit of financial statements in terms of time required in the examination, as well as the number of assignments that have been done.

Auditor professionalism and level of materiality are important in auditing the financial statements of an entity. Both auditor professionalism and level of materiality are covered by auditing standards. Common auditing standards relate to the competencies and attitudes an auditor must possess in performing his or her duties, while materiality relates to fieldwork standards and reporting standards. Professionalism becomes a critical issue for the accounting profession because auditor professionalism describes the performance of the auditor. The image of professionalism is reflected in the five dimensions of dedication to the profession, namely: social obligation, independence, confidence in the profession, and relationships with colleagues [3].

The accounting profession is required to have principles and morals, as well as ethical behavior that are in accordance with ethics. Understanding the role of an auditor's ethical behavior can have a broad effect on how to behave towards their clients in order to behave in conformity with generally accepted accounting rules [2], [4]. Being ethical in accordance with professional ethics shows that an auditor is able to commit well in carrying out his or her duties.

Public and government auditors, as a profession, are required to provide high trust and have an important role in a country. Ethical application is a major requirement that cannot be negotiated. If the auditor is doing his or her work in an unethical and immoral manner, even if the result is in accordance with the plan, it will be not worth its value. The attitudes that must be met in professional accountant include competence, wisdom, honesty, credibility, good morality, objectivity, transparency, among others. However, all of these factors will not work without the public accountant being ethical in his or her duties. 
Research on auditor behavior is very important. This is an interesting issue that has been studied extensively by previous researchers. Haynes [1] suggests that many factors may affect auditor judgments, such as client preferences and audit experience. While research results from Susetyo[5] show that audit experience has no effect on an auditor's judgment, Alvina and Suryanawa[6] in their research showed a relationship between auditor professionalism and the consideration of materiality in auditing financial statements having a positive and significant relationship. Putu [7], showed that professionalism, work experience, and auditor education have significant positive effects on the materiality level, and Sukma's[8], research showed that professionalism has no effect on materiality consideration.

Based on previous findings, this is a joint study of previous research conducted by Hastuti [3], Susetyo[5], Alvina and Suryana[6], and Putu [7]. This includes auditor professionalism, auditor experience, professional ethics, and materiality considerations.

\section{Method}

The research approach used in this study was quantitative research with descriptive research. The sampling technique used is purposive sampling where the criteria of respondents in this study include auditors who already have audit experience. Data was obtained by distributing questionnaires to respondents by going directly to the location of sampling. The questionnaire is entrusted to be filled by the auditor working in the BPKP Representative Office of South Sulawesi Province. The total population in this study is all government auditors within the scope of Makassar. The questionnaire was distributed from 19 June 2017 to 28 July 2017. Of the 100 questionnaires distributed, a total of 73 questionnaires were returned, and 69 of the questionnaires were usable in this study.

The questionnaire consisted of 74 points where 24 points were on auditor professionalism, 9 on auditor experience, 23 points on professional ethics, and 18 points on materiality consideration. In determining the weight of each answer, the respondents were asked to give a score (value) for each answer using the Likert scale.

Multiple linear regression analysis method was used in this research with the aim of knowing whether there is an influence of the dependent variables on the dependent variable. The statistical calculation in multiple linear regression analysis used with the help of the SPSS computer program. The significance level used in this study was the $0.05(5 \%)$ threshold. To examine the effect of auditor professionalism, the experience of the auditor, the professional ethics on materiality considerations.

\section{Result and Discussion}

\subsection{Respondent Characteristics}

The data characteristics of the respondents in this study include the respondents' position, educational background, length of work, and gender. The total number of respondents who are senior auditors is $16(23 \%)$ and junior auditors is $53(77 \%)$. The total number of respondents with a doctorate degree is $1(1 \%)$, a master's degree is $3(4 \%)$, a bachelor's degree is 54 (79\%), and an associate's degree is $11(16 \%)$. Respondents who have worked for less than one year were 0 , between 1 and 5 years were 20 (29\%), between 6 and 10 years were $11(15 \%)$, and more than 10 years were $38(56 \%)$. There were 39 male respondents $(57 \%)$ and 30 female respondents (43\%). The analysis was conducted on 69 respondents who have met the criteria to be further processed. Results of statistical descriptive data processing showed the variables of auditor professionalism obtained an average of 3.957 with a standard deviation of 0.2054 . This average value indicates that the auditor professionalism variable reported by the 
respondents is relatively high. The average value for the auditor experience variable was 4.014 with a standard deviation of 0.3205 , professional ethics average value of 4.043 with a standard deviation of 0.2676 , and materiality considerations with an average value of 3.957 with a standard deviation of 0.2054 .

\subsection{Validity and Reliability Testing}

A validity test is used to measure the validity of the questionnaire used. The technique used to test validity is the Pearson correlation coefficient. Data is said to be valid if the total of each construct is at the 0.05 or 0.01 level. The results of the validity testing in this study can be seen in the following table.

Table 1. Validity Testing Results

\begin{tabular}{lllc}
\hline Variable & $\begin{array}{l}\text { Pearson Correlation } \\
\text { (Validity) }\end{array}$ & Sig. (2-tailed) & Validity \\
\hline Auditor Professionalism (X1) & 0.402 & 0.01 & Valid \\
Auditor Experience (X2) & 0.307 & 0.01 & Valid \\
Professional Ethics (X3) & 0.262 & 0.01 & Valid \\
Materiality Considerations (Y) & 0.280 & 0.01 & Valid \\
\hline
\end{tabular}

Source: Primary Data, 2017

The result of the validity test in Table 1 shows the Pearson correlation for each variable, namely the application of governmental accounting standards ( $y$ ) and the utilization of information technology at the 0.05 or 0.01 significance level. Thus, it can be concluded that all questionnaire questions are able to measure the expected variables.

The reliability test is measured by using Cronbach's Alpha $(\alpha)$ statistical test. If Cronbach's Alpha value is greater than 0.60 , then the data is said to be reliable. The results of the reliability test in this study can be seen in the following table:

Table 2. Reliability Testing Results

\begin{tabular}{lll}
\hline Variable & Cronbach's & Reliability \\
& Alpha $(\alpha)$ & \\
\hline Auditor Professionalism (X1) & 0,812 & Reliable \\
Auditor Experience (X2) & 0,869 & Reliable \\
Professional Ethics (X3) & 0,812 & Reliable \\
Materiality Considerations (Y) & 0,811 & Reliable \\
\hline
\end{tabular}

Source: Primary Data, 2016

Based on the results of reliability testing shown in Table 2, the Cronbach's Alpha value for each variable is greater than 0.60 (Nunnally, 1967) in [9]. Thus, it can be concluded that the question for each variable is said to be reliable. 


\subsection{Classical Assumption Testing}

Classical assumption testing was done to include the multicollinearity test, outcome test, heteroscedasticity test, and normality test. The multicollinearity test results show that the regression model has a correlation level of -0.678 or about $67.8 \%$. Because this correlation is below $95 \%$, it can be said that there is no serious multicollinearity. This indicates that there is no 0 tolerance value that is below 0.10 and no VIF value above 10 . Thus, the regression model used in this study did not find any collinearity between independent variables.

The autocorrelation test used was the Durbin-Watson (DW) test. This value is then compared to the DW table. To be free of autocorrelation, the DW value must be greater than the lower limit (dl) and less than 4-upper limit (4-du). The regression model in this research is free of autocorrelation. The DW value is 1.454 when compared to the value of the table with a significance value of 5\% of the sample number (n) 69 and the number of independent variables $2(\mathrm{k}=2)$. The DW value of 1.454 is greater than the upper limit $(\mathrm{du})$ of 1,662 and less than 4-1.662. This is because the DW value is larger than the lower limit value and less than 4-du, so it can be concluded there is no autocorrelation. While the scatter plot shows that the points are spread randomly and both above and below the number 0 on the $\mathrm{Y}$ axis, it can be concluded that there is no heteroscedasticity on the regression model, so that the regression model is appropriate to predict the consideration of materiality based on the independent variables.

The normality test results of the data in this study show spots spread close and around the diagonal line. If the data is spread around and follows the direction of the diagonal line, then it is said to be normal distribution. The histogram graph gives the skewness pattern to the left or right, and the histogram graph shows the normal distribution pattern. The regression model meets the assumption of normality [9]. The Kolmogorov-Smirnov test was performed to strengthen the graph. Based on these statistical tests, the Kolmogorov-Smirnov value is 3.944 and asymp.sig. (2-tailed) is 0.000 because the level of significance is more than 0.05 . The residual is said to have a normal distribution.

\subsection{Hypotheses Testing}

Testing the hypotheses aims to see whether auditor professionalism, auditor experience, and professional ethics partially affect the judgment of auditor materiality.

The coefficient of determination (R2) measures the ability of the model in explaining the variation of the dependent variable is the employee's performance against the independent variables of auditor professionalism, auditor experience, and professional ethics. In the test results of multiple linear regression analysis, it is known that the coefficient of determination (R2) or adjusted R2 obtained by 0.488 . This means that $48.8 \%$ of materiality considerations can be explained by auditor professional variables, auditor experience, and professional ethics, while the remaining $51.20 \%$ of materiality considerations are influenced by other variables not examined in this study. In addition, the value of $\mathrm{R}$ obtained is 0.715 or $71.5 \%$ which means that there is a strong relationship between auditor professionalism, auditor experience, and professional ethics on materiality considerations, presented in table 3 .

The coefficient of determination (R2) measures how capable the model is in explaining the variation of the dependent variables, namely employee performance which is measured in auditor professionalism, experience, and professional ethics. In the multiple regression analysis, the adjusted R2 is 0.48 . This indicates that $48.8 \%$ of materiality considerations can be explained by the independent variables, and the remaining $51.2 \%$ are affected by other variables not examined in this study. In addition, the $\mathrm{R}$ value of $71.5 \%$ means that there is a strong relationship between auditor professionalism, experience, and professional ethics on materiality considerations as shown in Table 3 . 
Table 3. Results of Multiple Regression Analysis

\begin{tabular}{cccccc}
\hline Model & $\mathrm{R}$ & $\mathrm{R}^{2}$ & Adjusted $\mathrm{R}^{2}$ & Std. Error of the Estimate & Durbin-Watson \\
\hline 1 & $.715^{\mathrm{a}}$ & .511 & .488 & .147 & 1.454 \\
\hline a. & Predictors (Constant), PA, PLA, EP & & \\
b. & Dependent Variable: PM
\end{tabular}

Table 4. Coefficientsa of Multiple Regression Analysis

\begin{tabular}{cccccc}
\hline \multirow{2}{*}{ Model } & \multicolumn{2}{c}{ Unstandardized Coefficients } & Standardized Coefficients & \multirow{2}{*}{ T } & Sig. \\
& $\mathrm{B}$ & Std. Error & Beta & & \\
\hline 1 (Constant) & 2.766 & .434 & & 6.398 & .000 \\
PA & -0.44 & .087 & -0.44 & -.504 & .616 \\
PLA & .563 & .076 & .878 & 7.435 & .000 \\
EP & -.224 & .091 & -.292 & -2.469 & 0.16 \\
\hline
\end{tabular}

a. Dependent Variable PM

Based on the results of the multiple regression analysis, the estimation model is as follows: $\mathrm{Y}=2.776-0.44 \mathrm{X} 1+0.563 \mathrm{X} 2-0.224 \mathrm{X} 2$

The estimation model shows that the constant is positive (2.776). This indicates that if the regression coefficient of the independent variable is positive then there is a direct relationship to the dependent variable. Conversely, if the regression coefficient of the independent variable is negative then there is an opposite relationship to the dependent variable.

The regression coefficient of the auditor professionalism (X1) variable is negative (-0.44). A negative value means that the auditor professionalism variable (X1) does not have a direct relationship to the materiality consideration variable. This means that if the auditor professionalism variable (X1) increases with the assumption that the audit experience variable (X2) and professional ethics (X3) remain constant, then the level of materiality consideration will decrease. The regression coefficient of the audit experience variable (X2) is positive (0.563). A positive value means that the auditor experience variable (X2) has a direct relationship to the materiality consideration variable. This means that if the auditor experience variable (X2) increases with the assumption that the auditor professionalism variable (X1) and professional ethics remain the same, then the materiality consideration will increase. Similarly, the regression coefficient of professional ethics variable (X3) is negative (-0.224). A negative value means that the professional ethical variable (X3) has no direct relationship to the materiality consideration variable. This means that if the professional ethical variable (X3) increases with the assumption that the auditor professionalism variable (X1) and professional ethics (X3) stay the same, then the level of materiality consideration will decrease.

Statistical t-test is used to partially test each variable so to know whether the independent variables have a significant effect or not on the dependent variable. The t-table value used is at the $5 \%$ significance level where the degrees of freedom $(\mathrm{db})=\mathrm{n}-\mathrm{k}(69-2=67)$ is 1.996 . Hypothesis testing is done by comparing the t-value with the t-table. The hypothesis is accepted if the $t$-count is greater than the $t$-table value or significance is less than or equal to 0.05 . The $t$-table value at the 0.05 significance level is 1.996 . For the auditor professionalism variable (X1), the significance value is 0.616 and the $t-v a l u e$ is -0.504 . This means that the auditor professionalism variable (X1) has no significant effect on the level of materiality 
consideration. The coefficient $\mathrm{b}$ of the auditor professionalism variable (X1) is negative (0.044) which means that auditor professionalism has no positive effect on materiality consideration so the first hypothesis is not accepted.

In testing the second hypothesis for the auditor experience variable (X4), the significance value is 0.000 and the $t$-value is 7.435 . The significance value of 0.00 is less than 0.05 and the $\mathrm{t}$-value is less than that of the t-table value, meaning that the auditor experience variable (X2) has a significant effect on the level of materiality consideration. The coefficient $b$ of the auditor experience variable (X2) is 0.563 which means that the auditors experience variable has a positive influence on materiality considerations so the hypothesis in this study accepted. While the third hypothesis test results for professional ethical variables (X3), the significance value is 0.16 and the $t$-count is -2.469 . The significance value of is less than the 0.05 threshold and the t-count is less than the t-table, meaning that the professional ethical variable (X3) has a significant influence on the level of materiality consideration. The coefficient $b$ of the professional ethical variable (X3) is negative $(-0.24)$, which means that professional ethics does not have a positive influence on materiality considerations, so the third hypothesis is not accepted.

These findings are consistent with Yendrawati's[10], study that examined the dimensions of auditor professionalism, namely dedication to the profession, social obligation, independence, belief in the profession, and professional relation, on materiality consideration. Only belief in profession had no significant relationship. Similarly, in the research of [6], their results showed that the auditor professionalism dimensions have a significant and positive correlation to materiality level in auditing financial statements, and Putu's [7], research showed empirical results that professionalism, work experience, and auditor education level had a significant positive effect on materiality level consideration. There is a positive correlation between the belief dimension and the profession with consideration of the level of materiality. However, these findings differ which indicated that professionalism, knowledge in detecting errors, and professional ethics significantly and positively affected materiality considerations of public accountants in the process of examining financial statements. These findings indicate that professional ethics, which are the principles of an auditor in the process of collecting and evaluating evidence to determine and report information discrepancy based on the criteria, are influenced by auditor professionalism so that in determining the materiality of a government auditor's ability to avoid any concealment or misstatement of the presentation, a government auditor is able to design inspections to provide reasonable assurance in order to detect material misstatements from non-compliance of laws and regulations.

F-test is used to determine the effect of independent variables simultaneously on the dependent variable. This test uses a significance level of 0.05 where if the significance value is less than 0.05 , then it can be said that there is a significant influence simultaneously between independent variables and the dependent variable. The simultaneous regression model parameters are obtained in the following table:

Tabel 5. Hasil Uji F

ANOVA $^{b}$

\begin{tabular}{|l|l|l|l|l|l|}
\hline Model & Sum of Squares & df & Mean Square & F & Sig. \\
\hline
\end{tabular}




\begin{tabular}{|ll|r|r|r|r|r|}
\hline $1 \quad$ Regression & 1.465 & 3 & .488 & 22.613 & $.000^{\mathrm{a}}$ \\
& 1.404 & 65 & .022 & & \\
Residual & 2.870 & 68 & & & \\
Total & & & & \\
\hline
\end{tabular}

a. Predictors: (Constant), EP, PA, PLA

b. Dependent Variable: PM

Table 5. Results of F-Test

ANOVA $^{\mathrm{b}}$

\begin{tabular}{|c|c|c|c|c|c|}
\hline Model & Sum of Squares & Df & Mean Square & F & Sig. \\
\hline Regression & 1.465 & 3 & .488 & 22.613 & $.000^{\mathrm{a}}$ \\
Residual & 1.404 & 65 & .022 & & \\
Total & 2.870 & 68 & & & \\
\hline
\end{tabular}

a. Predictors: (Constant), EP, PA, PLA

b. Dependent Variable: PM

Testing the fourth hypothesis is done by comparing the value of Fcount with the F-table value. The hypothesis can be accepted if F-count is greater than Ftable or the significance value is less than 0.05 . The F-table value at the 0.05 significance level is 3.13 . The significance value for the simultaneous test is 0.000 and F-count is 22.613 so it can be concluded that there is a positive and significant influence simultaneously between auditor professionalism (X1) auditor experience (X2), and professional ethics (X3) on materiality considerations $(\mathrm{Y})$ so that the fourth hypothesis is accepted.

This finding is the research is different from Susetyo's [5], which showed that audit experience did not significantly affect the auditor's consideration, while audit experience on auditor considerations was moderated by the client's credibility as a quasi moderator. While the credibility of the client as a moderator between the relationship between professionalism, professional ethics, and experience on the level of materiality indicates that auditor professionalism has a significant and negative effect on materiality considerations, there is no significant effect between professional ethics on materiality considerations, experience has no effect on materiality, the client's credibility significantly moderates the influence between the auditor's professionalism on materiality considerations, and the client's credibility significantly moderates the influence of professional ethics on materiality considerations (Utami and Adhi [2].

These findings indicate that professional ethics, experience, auditor professionalism affect the judgment of the auditor's materiality. The auditor's experience in auditing financial statements is very influential from the time aspect and the number of assignments performed. The experience of a government auditor is related to materiality considerations because the 
auditor's experience is related to the expertise and knowledge in handling a case, and if an auditor has strong professional ethics then he or she is capable of influencing materiality considerations in auditing.

\section{Conclusion}

Based on the results of this research and hypothesis testing, it can be concluded that auditor professionalism has no positive and significant impact on the consideration of materiality auditor experience has a positive and significant impact on materiality considerations professional ethics has no positive and significant effect on materiality considerations and auditor professionalism, auditor experience, and professional ethics simultaneously have a positive and significant impact on materiality considerations for government auditors in Makassar.

From these findings, it is suggested that the government auditor, in conducting an audit, to improve his or her compliance toward professional ethics and to prioritize professionalism values in auditing. For future research, is expected to use other variables that affect auditor materiality considerations.

\section{References}

[1] C. M. Haynes, J. G. Jenkins, and S. R. Nutt, "The Relationship between Client Advocacy abd Audit Experience: An Exploratory Analysis," Audit. A J. Pract. Theory, vol. 17 , no. 20, pp. 88-104, 1998 .

[2] G. Utami and A. M. Nugroho, "Pengaruh Profesionalisme Auditor, Etika Profesi dan Pengalaman Auditor terhadap Pertimbangan Tingkat Materialitas dengan Kredibilitas Klien sebagai Pemoderasi,” J. Nominal, vol. III, no. 1, 2014.

[3] T. D. Hastuti, S. L. Indriarto, and C. Susilawati, "Hubungan antara Profesionalisme dengan Pertimbangan Tingkat Materialitas dalam Proses Pengauditan Laporan Keuangan," Pros. Simp. Nas. Akunt. VI, pp. 1202-1220, 2003.

[4] M. B. Curtis, C. L. Teresa, and C. C. Lawrence, "A Cross-Cultural Study of the Influence of Country of Origin, Justice, Power Distance, and Gender on Etical Decision making," J. Int. Account. reserach, vol. 11, no. 1, pp. 5-34, 2012.

[5] B. Susetyo, "Pengaruh pengalaman Audit terhadap Pertimbangan Auditor dengan Kredibilitas Klien Sebagai variabel Moderating," in Thesis, 2009.

[6] N. Alvina and I. S. Ketut, "Analisis Hubungan antara Profesionalismr Auditor dengan Pertimbangan Tingkat Materialitas dalam Proses Pengauditan Laporan Keuangan ( studi Empiris pada Kantor Akuntan Publik di Bali).” Universitas Udayana (Tidak Dipublikasikan), Bali, 2011.

[7] L. E. Putu, "Pengaruh Profesionalisme, Pengalaman Kerja dan Tingkat Pendidikan auditor terhadap Pertimbangan Tingkat materialitas (Studi Empiris pada Kantor Akuntan Publik di Wilayah Bali)," J. Ilm. Akunt. dan Humanika, vol. 3, no. 1.

[8] E. Sukma, "Pengaruh Profesionalisme, Etika Profesi, Tingkat Pendidikan dan Pengalaman Kerja Auditor pada Pertimbangan Tingkat Materialitas Audit Laporan Keuangan," in Skripsi, 2010. 
[9] I. Ghozali, Aplikasi Analisis Multivariate Dengan Program SPSS. Semarang: Badan Penerbit Universitas Diponegoro, 2007.

[10] R. Yendrawati, "Analisis Hubungan antara Profesionalisme Auditor dengan Pertimbangan Tingkat Materialitas dalam Proses Pengauditan Laporan Keuangan," $J$. Fenom., vol. 6, no. 1, 2008. 